\title{
Influence of antifouling paint on freshwater invertebrates (Mytilidae, Chironomidae and Naididae): density, richness and composition
}

\author{
D. S. Fujita, ${ }^{a, b *}$, A. M. Takeda ${ }^{c}$, R. Coutinho ${ }^{d}$ and F. C. Fernandes ${ }^{d}$ \\ aPrograma de Pós-graduação em Ecologia de Ambientes Aquáticos Continentais, Universidade Estadual de Maringá - \\ UEM, Av. Colombo, 5790, Jardim Universitário, CEP 87020-900, Maringá, PR, Brazil \\ 'Instituto Federal de Educação, Ciência e Tecnologia de Roraima - IFRR, Campus Amajari, RR 342, \\ Vicinal de acesso à Balsa de Aparecida, Km 03, CEP 69343-000, Amajari, RR, Brazil \\ 'Departamento de Biologia, Universidade Estadual de Maringá - UEM, Av. Colombo, 5790, Jardim Universitário, \\ CEP 87020-900, Maringá, PR, Brazil \\ dDepartamento de Oceanografia, Instituto de Estudos do Mar Almirante Paulo Moreira - IEAPM, Rua Kioto, 253, \\ CEP 28930-000, Arraial do Cabo, RJ, Brazil \\ *e-mail: danielefujita@gmail.com
}

Received: April 10, 2014 - Accepted: August 15, 2014 - Distributed: November 30, 2015

(With 7 figures)

\begin{abstract}
We conducted a study about invertebrates on artificial substrates with different antifouling paints in order to answer the following questions: 1) is there lower accumulation of organic matter on substrates with antifouling paints, 2) is invertebrate colonization influenced by the release of biocides from antifouling paints, 3 ) is the colonization of aquatic invertebrates positively influenced by the material accumulated upon the substrate surface and 4) is the assemblage composition of invertebrates similar among the different antifouling paints? To answer these questions, four structures were installed in the Baía River in February 1 1, 2007. Each structure was composed of 7 wood boards: 5 boards painted with each type of antifouling paints (T1, T2, T3, T4 and T5), one painted only with the primer (Pr) and the other without any paint (Cn). After 365 days, we observed a greater accumulation of organic matter in the substrates with T2 and T3 paint coatings. Limnoperna fortunei was recorded in all tested paints, with higher densities in the control, primer, T2 and T3. The colonization of Chironomidae and Naididae on the substrate was positively influenced by L. fortunei density. The non-metric multidimensional scaling (NMDS) of the invertebrate community provided evidence of the clear distinction of invertebrate assemblages among the paints. Paints T2 and T3 were the most similar to the control and primer. Our results suggest that antifouling paints applied on substrates hinder invertebrate colonization by decreasing the density and richness of invertebrates.
\end{abstract}

Keywords: colonization, biofouling, Limnoperna fortunei.

\section{Influência de revestimentos antiincrustantes em invertebrados aquáticos (Mytilidae, Chironomidae and Naididae): densidade, riqueza e composição}

\section{Resumo}

O estudo dos invertebrados em substrato artificial com diferentes revestimentos antiincrustantes foi realizado com o intuito de responder as seguintes questões: 1) Há menor acumulação de material orgânico nos substratos com revestimentos antiincrustantes? 2) A colonização de invertebrados é afetada pela liberação de biocidas dos revestimentos antiincrustantes? 3) A colonização dos invertebrados aquáticos é facilitada por material acumulado sobre a superfície do substrato? 4) A composição da assembléia é similar entre os diferentes revestimentos? Para realização deste estudo, quatro estruturas foram instaladas em 01 de fevereiro de 2007 no rio Baía. Em cada estrutura foram colocadas sete placas de madeira: cinco placas com aplicação de um tipo de revestimentos antiincrustantes (T1, T2, T3, T4 e T5), uma placa apenas com a aplicação do primer (Pr) e a outra placa permaneceu sem aplicação de nenhum revestimento (Cn). Ao final dos 365 dias em que os substratos ficaram submersos observou-se maior acumulação de material orgânico nos substratos dos revestimentos T2 e T3. Limnoperna fortunei foi registrada em todos os revestimentos testados, com maiores densidades encontradas no controle, primer, T2 e T3. A colonização de Chironomidae e Naididae sobre os substratos foi influenciada pela densidade de L. fortunei. A ordenação (NMDS) evidenciou a separação da assembléia de invertebrados entre os revestimentos. Os revestimentos T2 e T3 foram os mais similares ao controle e ao primer. Os resultados obtidos sugerem que revestimentos antiicrustantes aplicados sobre substratos dificultam a colonização de invertebrados, reduzindo a densidade e riqueza de invertebrados.

Palavras-chave: colonização, bioincrustação, Limnoperna fortunei. 


\section{Introduction}

Bioaccumulation, or biofouling, is the accumulation or unwanted growth of microorganisms, plants or animals on the surface of an object (natural or artificial) that is immersed in the water (WHOI, 1952). Algae, hydrozoans and mollusks are the main organisms responsible for fouling in freshwater (Callow, 1993). Limnoperna fortunei is a bivalve from Asia that was introduced in the Neotropical region (Darrigran and Pastorino, 1995). It attaches upon solid substrates and/or other organisms using byssus fibers (Darrigran and Damborenea, 2006; Mansur and Pereira, 2006; Santos et al., 2012).

Once in South American rivers, the dispersal of $L$. fortunei can occur through natural mechanisms. Planktonic larvae are dispersed by the current flow and juveniles and adults are dispersed by the attachment to floating elements or other organisms (Darrigran and Damborenea, 2006) or some fish species are important dispersal vectors for invading L. fortunei (Belz, et al., 2012). Dispersal can also occur through non-natural mechanisms, such as shipping and fisheries activities (Garcia and Protogino, 2005; Darrigran and Mansur, 2006). The ability to attach to ship hulls and, consequently, to be transported to other places may be one of the main dispersal mechanisms of this species (Darrigran, 2002; Takeda et al., 2003, 2011).

The concern of protecting equipment or industrial installations from bioaccumulation, especially by L. fortunei (Darrigran et al., 2007; Darrigran and Damborenea, 2006; Portella et al., 2009), has driven researchers to find ways to prevent and control the macrofouling upon solid structures. Some solutions include antifouling material (Ohkawa et al., 1999; Faria et al., 2006), molluscide and other biocides (Maroñas and Damborenea, 2006) and antifouling paints (Caprari and Lecot, 2001; Matsui et al., 2002; Caprari, 2006).

The antifouling paint prevents an organism from attachment due to the toxic properties of the paint (Caprari and Lecot, 2001). The toxicity also assures effective long-term protection. However, by possessing biocide components in their composition, these paints release particles of biocide pigments, such as copper, into the water (Omae, 2003; Yebra et al., 2004). At high concentrations, these biocide pigments may be harmful to aquatic organisms, such as benthic invertebrates (Kraft and Sypniewski, 1981) and fish (Barry et al., 2000; Marr et al., 1999).

The project "Programa de pesquisa para controle do mexilhão dourado (Limnoperna fortunei) nas águas jurisdicionais brasileiras" was coordinated by the Instituto de Estudos do Mar Almirante Paulo Moreira conducted bioassays in the laboratory and in the field using several antifouling paints found in Brazilian commerce. The purpose of the project was to identify paints that prevent the attachment of the golden mussel; with lower environmental costs (IEAPM, 2008). From the project's results, we selected five antifouling paints and evaluated their effects on other species of aquatic invertebrates.
Our study concerning invertebrates on artificial substrates with different antifouling paints was performed in order to answer the following questions: 1) is there lower accumulation of organic matter on substrates with antifouling paints, 2) is invertebrate colonization influenced by the release of biocides from antifouling paints, 3 ) is the colonization of aquatic invertebrates positively influenced by the material accumulated upon the substrate surface and 4 ) is the assemblage composition of invertebrates similar among the different antifouling paints? The hypothesis of our study was that the application of antifouling paints upon a substrate forms a pellicle that, due to its biocide attribute, hinders the colonization by aquatic invertebrates. We tested the following predictions: 1) there is lower accumulated organic matter, density and species richness on the substrate with antifouling paints and 2) the composition of invertebrate assemblage is different among the distinct paints.

\subsection{Study area}

The experiment was carried out in the inferior stretch of Baía River, located in the Environmental Protection Area (EPA) of Islands and "Várzeas" of the Paraná River (Figure 1). Baía River rises in Nova Andradina County (450 $\mathrm{m}$ above the sea level) and flows for $130 \mathrm{~km}$ until its confluence to the Paraná River, through Curutuba Channel, and to Ivinhema River. It is a sinuous river with varied width and several levees occupied by riparian vegetations, flooded or anthropized fields. The Baía River also has several aquatic macrophyte stands associated with its banks. In our sampling station $\left(22^{\circ} 41^{\prime} 9,39^{\prime \prime}\right.$ and $53^{\circ}$ $\left.15^{\prime} 8,67^{\prime \prime}\right)$ the mean depth was $3 \mathrm{~m}$ and the current flow was $0.02 \mathrm{~m} . \mathrm{s}^{-1}$.

The Baía River was chosen to perform this study because it presents a well-established population of the invasive species L. fortunei, with high densities of adult and larval stages. This was also an ideal study site because there is previous knowledge of other aquatic invertebrate taxa in the Baía River (Takeda et al., 1997; Takeda and Fujita, 2004; Behrend et al., 2009).

\section{Material and Methods}

In this experiment, the five antifouling paints tested were selected by choosing a combination of efficiency in the inhibition of the attachment of the golden mussel as well as low toxicity. These paints were selected based on laboratory bioassays previously performed by Coutinho et al. (2012). These tests also revealed the presence of copper oxide $\left(\mathrm{Cu}_{2} \mathrm{O}\right)$ in all of the antifouling paints.

Four structures were built to install the wood boards for the artificial substrate structure. Each structure was composed of a rigid PVC tube that was $1 \frac{1 / 4}{}$ ' in diameter and $2 \mathrm{~m}$ in length. The PVC tube was connected to a buoy anchored to the river bottom by cables at each end of the tube. The wood boards ( $20 \mathrm{~cm}$ wide, $25 \mathrm{~cm}$ tall and $15 \mathrm{~mm}$ thick) were pierced by the PVC tube and locked in place by copper wires to avoid contact among them. 


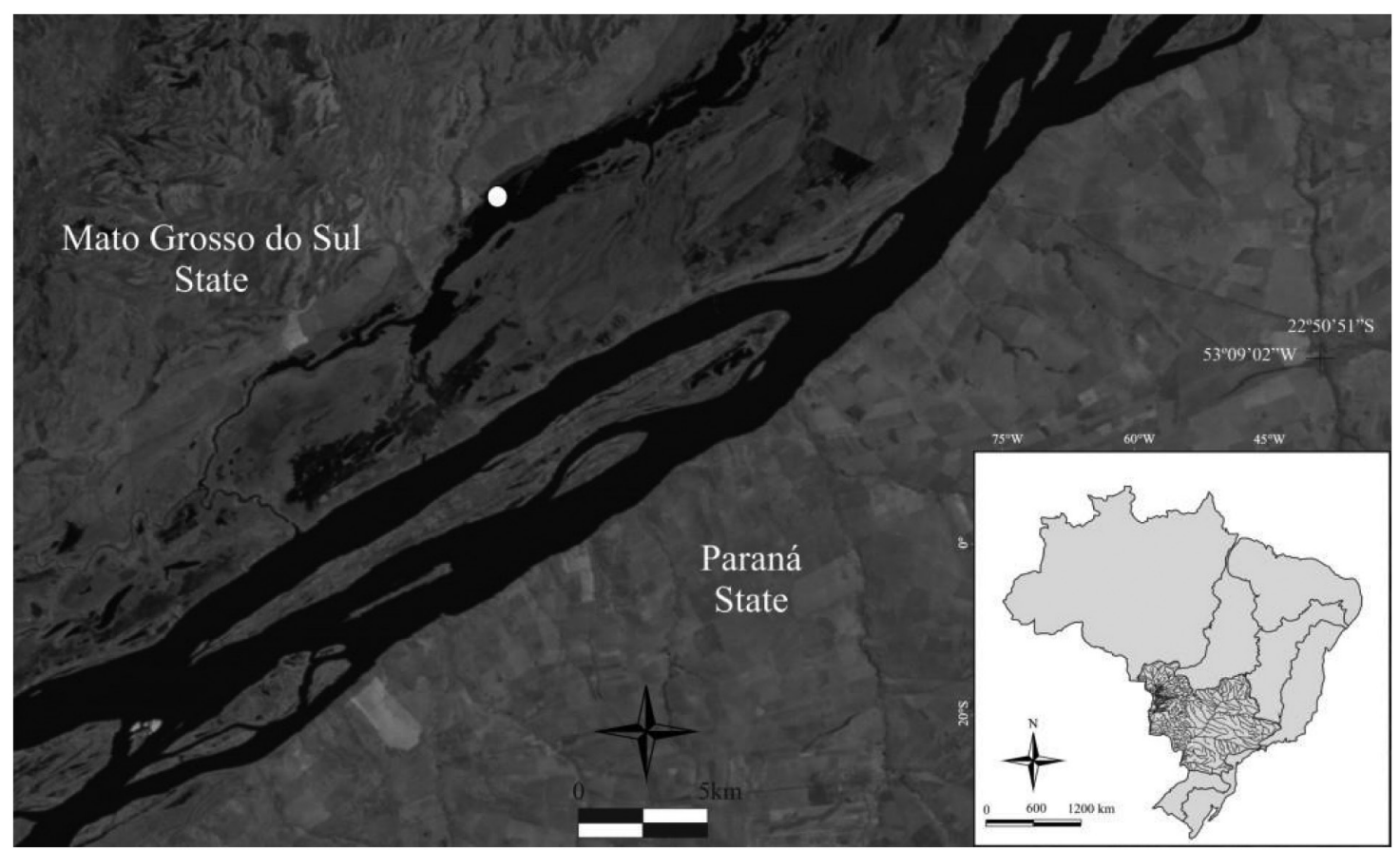

Figure 1. Map of the study area. Sampling point.

Each structure had seven wood boards (Table 1). Each of the five antifouling paints was applied to a board, one board only had the primer applied and the final board remained without any coating and was considered the control $(\mathrm{Cn})$. The primer is a paint that assures the adherence of the antifouling coating on the applied surface. The board arrangement was not randomized. The structures for the experiment were planned and created by the Instituto de Estudos do Mar Almirante Paulo Moreira. The structures were submerged in the Baía River on February 1 ${ }^{\text {st }}, 2007$.

\subsection{Sampling}

Samples from each wood board were taken on February $1^{\text {st }}, 2008$, after 12 months of exposure. The wood boards were scraped with a brush and the collected material was immediately preserved with alcohol (70\%).

The aquatic invertebrates from the samples were sorted and counted under a stereoscopic microscope. Oligochaeta and Chironomidae invertebrates were identified to the lowest taxonomic category possible using specialized literature (Oligochaeta: Brinkhurst and Jamieson, 1971; Brinkhurst and Marchese, 1991; Righi, 1984; Chironomidae: Trivinho-Strixino and Strixino, 1995; Coffman and Ferrigton, 1996; Epler, 1995).

After the removal of invertebrates from each sample, the remaining sample was dried in laboratory oven at $50^{\circ} \mathrm{C}$ and weighed to quantify the accumulated organic matter (dry weight).

\subsection{Data analysis}

We used R software (version 2.8, The R Foundation for Statistical Computing 2008, vegan package) to analyze the data. We used an analysis of variance (ANOVA) to
Table 1. List of used coatings and codes.

\begin{tabular}{ccc}
\hline Code & & Marca comercial \\
\hline Cn & Control & \\
& (without any coating) & \\
T1 & Antifouling paint & Revran AF BR 870 \\
T2 & Antifouling paint & Poliepox 600 \\
T3 & Antifouling paint & Revran AF LCL 870 \\
T4 & Antifouling paint & Coper Bottom 60 \\
T5 & Antifouling paint & Aemme Long Life Plus \\
Pr & Primer & \\
\hline
\end{tabular}

determine differences in accumulated organic material on the paint substrates and the control. Specifically, the ANOVA examined differences in the following factors: invertebrate density, invertebrate richness, density of L. fortunei and density of Chironomidae and Naididae. To describe the assemblage of aquatic invertebrates from artificial substrate, we analyzed the density (ind. $\mathrm{m}^{-2}$ ), abundance (\%) and taxa richness (S). The assumptions of normality and homoscedasticity were achieved after $\log$ transformations $\left(\log _{(\mathrm{n}+1)}\right)$.

The Spearman Correlation Coefficient was used to evaluate the correlation between the accumulated organic material and the invertebrate density (L.fortunei, Chironomidae and Naididae) and the correlation between L. fortunei, Chironomidae and Naididae densities.

The assemblage composition was examined using non-metric multidimensional scaling (NMDS) once zero values were removed. The Bray-Curtis distance was used to determine similarity in community composition among the samples. Differences in the community structure 
among the paint types were tested using the analysis of similarities (ANOSIM).

The coefficient of community loss (Courtemanch and Davies, 1987) was calculated for all paints. The control $(\mathrm{Cn})$ and the primer $(\mathrm{Pr})$ were used as reference. This is a dissimilarity index, for which the values increase according to the dissimilarity degree between the reference station and the interest station (Courtemanch and Davies, 1987).

\section{Results}

At the end of the 365 days in which the substrates remained submerged in the Baía River, we observed a greater accumulation of organic matter in the substrates with T2 and T3 paints (Figure 2). The analysis of variance found significant differences among the substrates (ANOVA: $\left.\mathrm{F}_{(6,21)}=7.33 ; \mathrm{p}<0.01\right)$, distinguishing $\mathrm{T} 2$ and $\mathrm{T} 3$ from the primer, T4 and T5 (Tukeys's Test; $\mathrm{p}<0.05$ ).

The density of invertebrates colonizing the substrates during the experiment ranged from 1 to 1,566 individuals, depending on the type of the paint. The invertebrate density (Figure 3a) and the number of taxa (Figure 3b) were significantly different between the substrates with and without antifouling paint $\left(\log _{(\text {Density }+1)}: \mathrm{F}_{(6,21)}=20.38\right.$; $\mathrm{p}<0.01$; Taxa: $\left.\mathrm{F}_{(6,21)}=15.83 ; \mathrm{p}<0.01\right)$.

High abundance and number of taxa were recorded in the control $(\mathrm{Cn})$ and primer $(\mathrm{Pr})$. Lower values were observed for the T4 and T5 antifouling paints (Figure 3). Limnoperna fortunei and Chironomidae were the most abundant taxa and were present on all substrates. Individuals from the Naididae Family (Oligochaeta) were only not recorded on $\mathrm{T} 4$.

Although L. fortunei was found on all substrates (Figure 4), its density differed among the paints $\left(\log _{(L . \text { fortunei }+1)}: \mathrm{F}_{(6,21)}=26.57 ; \mathrm{p}<0.01\right)$. Specifically, T1, T4 and $\mathrm{T} 5$ were different from the other coatings and from the control. Significant differences in Chironomidae and Naididae densities between the antifouling paints and the control were also evident (Chironomidae: $\mathrm{F}_{(6,21)}=6.17$; $\mathrm{p}<0.01$; Naididae: $\left.\mathrm{F}_{(6,21)}=2.65 ; \mathrm{p}<0.05\right)$. The lowest densities

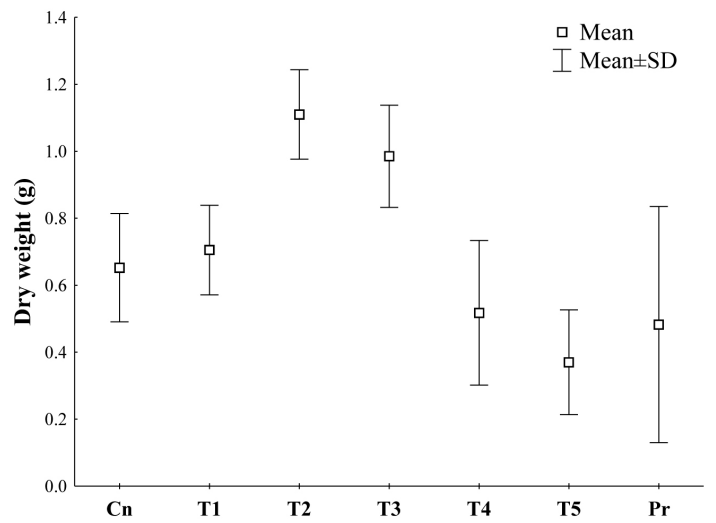

Figure 2. Mean and standard deviation of dry weight (g) of organic material accumulated on the substrates. $\mathrm{Cn}=\mathrm{Control}$, T1, T2, T3, T4, and T5=Antifouling paints, $\mathrm{Pr}=$ Primer. of Chironomidae and Naididae were recorded in T1, T4 and $\mathrm{T} 5$ paints (Figure 5).

Accumulated organic material was only correlated with Chironomidae density (Spearman correlation coefficient: $\rho=0.54 ; p<0.05)$. Positive correlations were found between L. fortunei $(\rho=0.74)$, the density of Chironomidae and Naididae $(\rho=0.51)$ and taxa richness $(\rho=0.82)$.
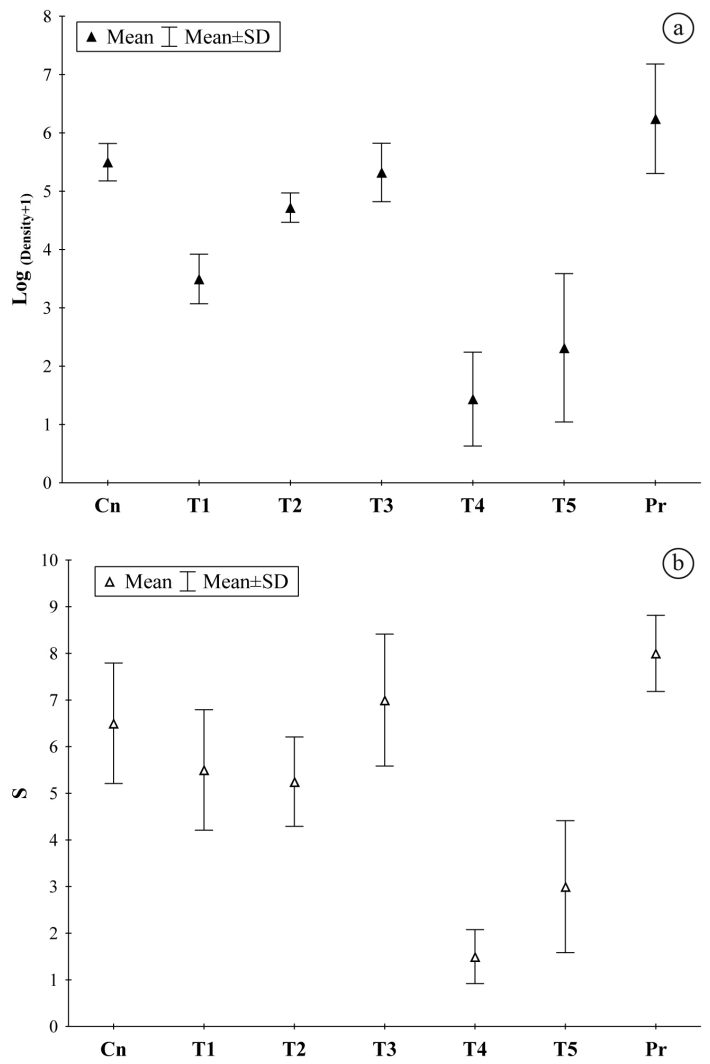

Figure 3. Mean and standard deviation of density $\left(\log _{\text {(Densidade+1) }}\right)$ (a) and number of taxa (b). $\mathrm{Cn}=$ Control, T1, $\mathrm{T} 2$, T3, T4, and T5=Antifouling paints, $\mathrm{Pr}=$ Primer.

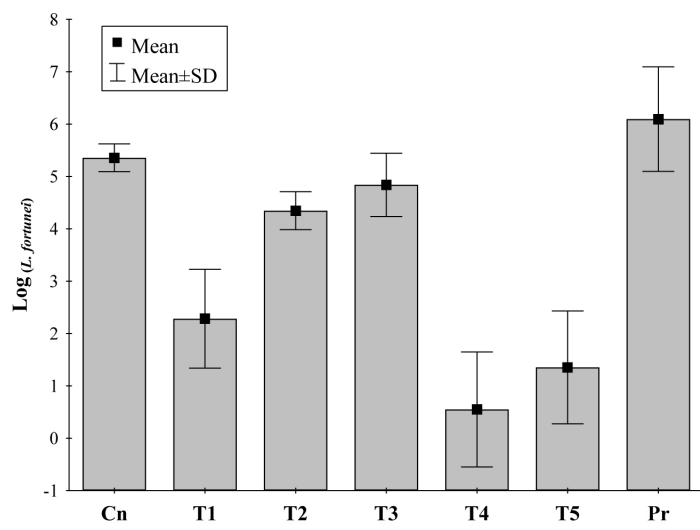

Figure 4. Mean and Standard deviation of $L$. fortunei density $\left(\log _{(L \text { fortunei+1) }}\right)$ among the substrates. $\mathrm{Cn}=\mathrm{Control}$, T1, T2, T3, T4, and T5=Antifouling paints, $\mathrm{Pr}=$ Primer. 

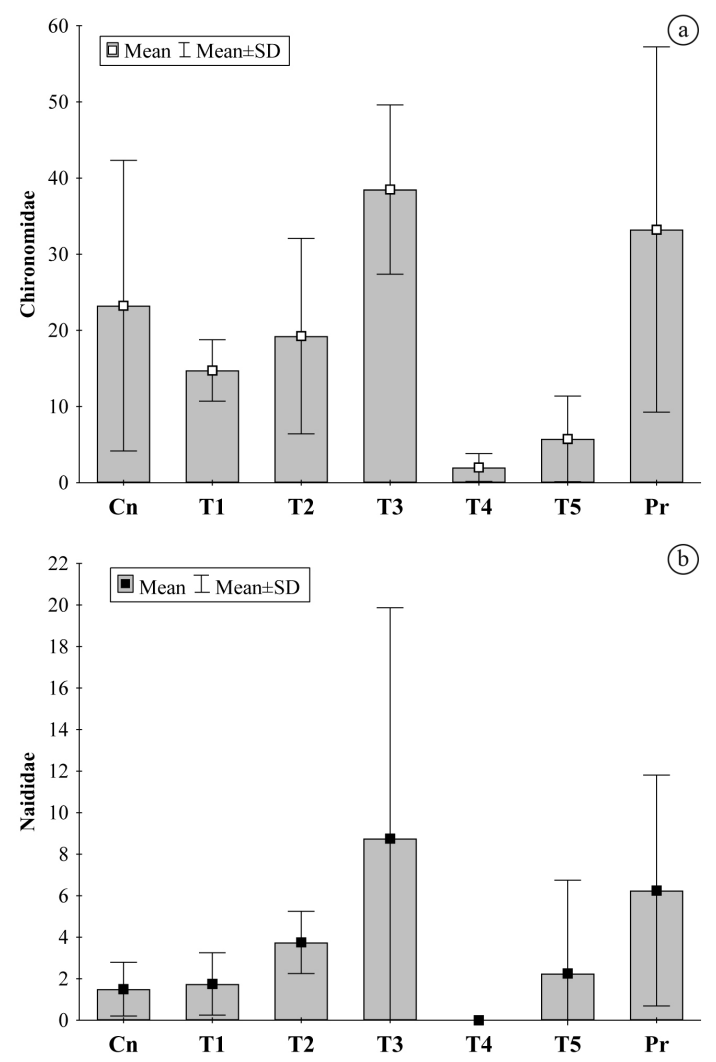

Figure 5. Mean and standard deviation of Chironomidae (a) and Naididae (b) density among the substrates. $\mathrm{Cn}=\mathrm{Control}$, T1, T2, T3, T4, and T5=Antifouling paints, $\mathrm{Pr}=$ Primer.

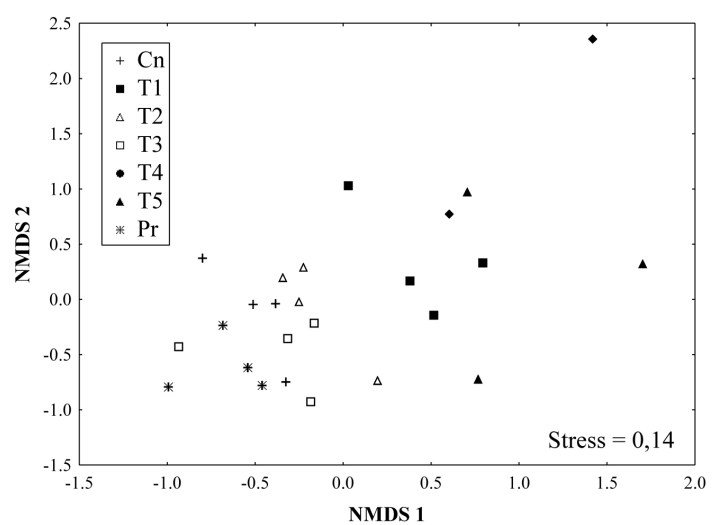

Figure 6. Non-metric multidimensional scaling (NMDS) of invertebrates community. $\mathrm{Cn}=\mathrm{Control}, \mathrm{T} 1, \mathrm{~T} 2, \mathrm{~T} 3, \mathrm{~T} 4$, and T5=Antifouling paints, $\mathrm{Pr}=$ Primer.

Among the 15 morphospecies of Chironomidae, Parachironomus sp4 was the most abundant in all paints. Only 7 species of Naididae were identified and their abundance varied depending on the paint (Table 2). Both the number of Chironomidae morphospecies and Naididae species that colonized the substrates differed among the paints, with a lower number of taxa on substrates with T4 and T5 paints.

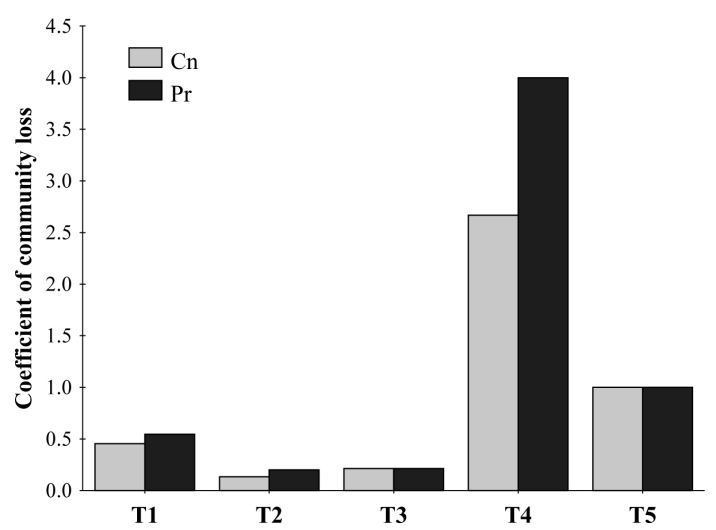

Figure 7. Values of the coefficient of community loss for the coatings. $\mathrm{Cn}=$ Control, T1, T2, T3, T4, and T5=Antifouling paints, $\mathrm{Pr}=$ Primer.

The ordination (NMDS) demonstrated the clear distinction of invertebrate communities among the paints (Figure 6). Additionally, the ANOSIM indicated that the communities were significantly different (ANOSIM: $\mathrm{R}=0.57 ; \mathrm{p}<0.01$ ). Regarding the composition of the invertebrate community, the T2 and T3 antifouling paints were more similar to the control and primer.

The values of the coefficient of community loss, using the control and primer as reference, indicated greater dissimilarity between the reference assemblages and those that colonized T4 and T5 (Figure 7).

\section{Discussion}

Antifouling paints are products whose application forms a pellicle containing biocides to prevent the fouling or accumulation of unwanted organisms upon an object's surface. The toxic action results in the biocide release, which is damaging to most organisms (WHOI, 1952). In general, the antifouling paints may repel the organisms because of organic changes that determine death before the attachment and/or permit the attachment but causing death during later stages of the life cycle (Caprari, 2006).

In the present study, we expected to record higher values of accumulated organic material in the substrates without antifouling paints (control and primer) due to the absence of a pellicle with biocide components. However, the greater accumulation of attached material was recorded in T2 and T3 paints, which favored higher colonization of invertebrates when compared to the other antifouling paints. Detritus, periphytic algae and bacteria that accumulate on the substrate provide food resources for several invertebrates (Bott and Borchardt, 1999), specifically Chironomidae larvae (Robinson et al., 1990; Armitage et al., 1995; Maasri et al., 2008) and Naididae species (Learner et al., 1978).

The accumulation of material in the T2 and T3 paints may be related to the adherence of the paints to the substrate surface, since any roughness (Howell and Behrends, 2006) may increase particle attachment. 
Table 2. Relative abundance (\%) of taxa recorded on the substrates. $\mathrm{Cn}=\mathrm{Control}, \mathrm{T} 1, \mathrm{~T} 2, \mathrm{~T} 3$, T4, and T5=Antifouling paints, $\operatorname{Pr}=$ Primer.

\begin{tabular}{|c|c|c|c|c|c|c|c|}
\hline & $\mathrm{Cn}$ & T1 & $\mathbf{T 2}$ & T3 & T4 & T5 & Pr \\
\hline \multicolumn{8}{|l|}{ Bivalvia } \\
\hline Limnoperna fortunei (Dunker, 1857) & 89.74 & 42.11 & 77.86 & 75.20 & 50.00 & 37.25 & 94.07 \\
\hline \multicolumn{8}{|l|}{ Chironomidae } \\
\hline Asheum & & 0.88 & 0.24 & & & & 0.04 \\
\hline Beardius sp1 & & 0.88 & & & & & \\
\hline Chironomus sp1 & 0.31 & 0.88 & & 0.66 & & & 0.04 \\
\hline Dicrotendipes sp3 & 0.21 & & 0.49 & & & & 0.04 \\
\hline Endotribelos sp1 & 0.10 & & 0.24 & 0.13 & & & \\
\hline Goeldichironomus gr pictus & & 2.63 & 0.49 & 0.26 & & 1.96 & 0.04 \\
\hline Parachironomus sp4 & 8.70 & 42.98 & 15.82 & 18.47 & 43.75 & 37.25 & 4.54 \\
\hline Polypedilum (Polypedilum) sp4 & & 0.88 & & 0.13 & & 3.92 & 0.08 \\
\hline Caladomyia $\mathrm{sp}$ & & & & & 6.25 & & \\
\hline Cricotopus sp1 & & & 0.24 & & & & 0.15 \\
\hline Corynoneura sp1 & & & 0.24 & & & & \\
\hline Nanocladius sp & 0.10 & 2.63 & 0.24 & & & & \\
\hline Ablabesmyia (Karelia) & 0.21 & & 0.24 & 0.26 & & 1.96 & 0.08 \\
\hline Djalmabatista sp & & & $<0.01$ & 0.13 & & & \\
\hline Labrundinia sp2 & & & 0.24 & 0.13 & & & \\
\hline \multicolumn{8}{|l|}{ Naididae } \\
\hline Chaetogaster diastruphus (Gruithuisen, 1828) & 0.10 & & & & & & \\
\hline Dero (Aulophorus) furcatus (Müller, 1773) & & 1.75 & & & & & \\
\hline Dero (Dero) sawayai Marcus, 1943 & & 3.51 & 1.46 & 0.66 & & 7.84 & 0.11 \\
\hline Nais communis Piguet, 1906 & 0.41 & 0.88 & 1.46 & 0.13 & & & 0.15 \\
\hline Pristina aequiseta Bourne, 1891 & 0.10 & & 0.49 & 3.56 & & & 0.11 \\
\hline Pristina leidyi Smith, 1896 & & & & 0.13 & & 9.80 & 0.23 \\
\hline Pristina proboscidea Beddard, 1896 & & & 0.24 & 0.13 & & & 0.34 \\
\hline Total of taxa & 10 & 11 & 15 & 14 & 3 & 7 & 14 \\
\hline
\end{tabular}

Additionally, the colonizing taxa may have a tolerance to the copper oxide released by these coatings. Several algae species (e.g., Achnanthes spp., Enteromorpha ssp. and Ectocarpus spp.) have a physiological tolerance to copper (French and Evans, 1986).

Limnoperna fortunei was recorded on all paints, although the higher densities were found on the substrates without antifouling paints (control and primer). The pigments extracted from all coatings were mainly composed of copper oxide $\left(\mathrm{Cu}_{2} \mathrm{O}\right)$ (IEAPM, 2008). Among the paints tested by Matsui et al. (2002), copper oxide can cause lower attachment of L. fortunei. Among the antifouling paints, T2 and T3 had greater attachment of L. fortunei at the end of 365 days, and this was probably due to the greater accumulation of organic matter. Furthermore, according to Faria et al. (2006), the presence of biofilm can increase the attachment of $L$. fortunei upon surfaces.

The colonization of Chironomidae and Naididae on the substrates was positively correlated with the density of L. fortunei, possibly because this bivalve promotes changes in the substrate surface, thereby creating a new microhabitat (Darrigran, 2002). Darrigran et al. (1998) also verified that the colonization by L. fortunei on solid surfaces (e.g., rocks) increased Oligochaeta colonization because of the increase in surface complexity. The increase in the abundance of detritivorous taxa, mostly Chironomidae and Naididae, probably increases the food resource availability, as well as release and disposal of wastes from mussels. In North America, of the presence zebra mussels (Dreissena polymorpha Pallas 1771), Ricciardi et al. (1997) increases the richness and abundance of macroinvertebrates due to the creation of habitat through mussel groupings and the accumulation of pseudofeces.

Among the Chironomidae morphospecies, Parachironomus sp4 was present and dominant (abundance $>70 \%$ ) in all paints. Parachironomus larvae are common in lentic environments with decaying organic matter (Sanseverino et al., 1998; Sanseverino and Nessimian, 2001; Rosin and Takeda, 2007). However, the dominance of the larvae from this morphospecies may be actually related to its life cycle, as higher densities have been recorded during February and March (Fujita and Takeda, in prep.).

It has also been observed that February is not a period with higher colonization of Naididae on substrates (Fujita and Takeda, in prep.), since it is a period when the water from the Paraná River invades the flooding area, which 
includes the Baía River (Thomaz et al., 2004). During this period, the lowest densities and richness of benthic invertebrates are observed (Rosin and Takeda, 2007; Behrend et al., 2009). However, this time period coincides with one of the higher recruitment periods for $L$. fortune $i$ (Takeda et al., unpublished data).

Nais communis, one of the principal species of Naididae that colonizes artificial substrates (Fujita and Takeda, in prep.), was abundant on the substrates without paint and absent in the T4 and T5 paints. This result may be due to the fact that $N$. communis does not have a chitin exoskeleton like insect larvae. As a result, annelids are more susceptible to the biocide released by antifouling paints.

The ordination (NMDS) demonstrated a clear distinction of invertebrate assemblages among the paints. Paints T2 and $\mathrm{T} 3$ (the substrates with the greatest accumulation of organic matter) were the most similar to the control $(\mathrm{Cn})$ and primer $(\mathrm{Pr})$ in terms of the composition of invertebrate communities. The T4 and T5 antifouling paints had lower attachment of $L$. fortunei (i.e., they were the most effective paints). This finding was also verified by Coutinho et al. (2012). However, the T4 and T5 paints were also those paints that most influenced the colonization of other aquatic invertebrates, as observed by the dissimilarity of those paints to the control and primer (NMDS and coefficient of community loss) and in the density and richness of Chironomidae and Naididae.

The results obtained by our study corroborate the hypothesis that antifouling paints applied upon substrates hinder invertebrate colonization (L. fortunei, Chironomidae and Naididae) by decreasing the density and richness. As a result, the assemblage has a reduced number of individuals and taxa (species and morphospecies). Nevertheless, the antifouling paints are applied to ship hulls (WHOI, 1952) and the release of biocides by the paints depends on several factors, as biocide solubility, exposed area, friction with surrounding water, water temperature and $\mathrm{pH}$ (Caprari, 2006). Therefore, research in other environments with distinct environmental conditions (current flow, temperature and $\mathrm{pH}$ ) may provide different results.

\section{Acknowledgements}

The authors thank CTHIDRO/CNPq (50.7675/2004-5) and the Núcleo de Pesquisas em Limnologia, Ictiologia e Aqüicultura (Nupelia) for financial and logistic support. We would like to thank CNPq and CAPES for a doctoral scholarship. Thank you to the following paint manufacturers for submitting their products: Renner Hermann S. A., Polipox, Sherwin-Willians Tintas Sumaré and Promar.

\section{References}

ARMITAGE, P.D., CRANSTON, P.S. and PINDER, L.C.V., 1995. The Chironomidae: the biology and ecology of non-biting midges. London: Chapman \& Hall. 572 p. http://dx.doi.org/10.1007/97894-011-0715-0.
BARRY, K.L., GROUT, J.A., LEVINGS, C.D., NIDLE, B.H. and PIERCEY, G.E., 2000. Impacts of acid mine drainage on juvenile salmonids in an estuary near Britannia Beach in Howe Sound, British Colombia. Canadian Journal of Fisheries and Aquatic Sciences, vol. 57, no. 10, pp. 2032-2043. http://dx.doi. org/10.1139/f00-157.

BEHREND, R.D.L., FERNADES, S.E.P., FUJITA, D.S. and TAKEDA, A.M., 2009. Eight years of monitoring aquatic Oligochaeta from the Baía and Ivinhema Rivers. Brazilian Journal of Biology = Revista Brasileira de Biologia, vol. 69, no. 2, suppl., pp. 559-571. http://dx.doi.org/10.1590/S151969842009000300011. PMid:19738963.

BELZ, C., DARRIGRAN, G., MÄDER NETTO, O. and RIBEIRO JUNIOR, P., 2012. Analysis of dispersion vectors in inland waters: the case of the invading bivalves in South America. Journal of Shellfish Research, vol. 31, no. 3, pp. 777-778. http://dx.doi. org/10.2983/035.031.0322.

BOTT, T.L. and BORCHARDT, M.A., 1999. Grazing of protozoa, bacteria, and diatoms by meiofauna in lotic epibenthic communities. Journal of the North American Benthological Society, vol. 18, no. 4, pp. 499-513. http://dx.doi.org/10.2307/1468382.

BRINKHURST, R.O. and JAMIESON, B.M.G., 1971. Aquatic Oligochaeta of the world. Edinburgh: Oliver and Boyd. 860 p.

BRINKHURST, R.O. and MARCHESE, M.R., 1991. Guia para la identificacion de oligoquetos aquáticos continentales de Sudy Centro America. Santo Tomé: Associacion de Ciencias Naturales del Litoral. 207 p.

CALLOW, M.E., 1993. A review of fouling in freshwaters. Biofouling, vol. 7, no. 4, pp. 313-327. http://dx.doi. org/10.1080/08927019309386262.

CAPRARI, J.J. and LECOT, C.J., 2001. El control de bivalvos invasores Limnoperna fortunei (Dunker, 1857) en la central hidroelétrica Yaciretá mediante pinturas. In: Actas Seminário Internacional sobre Gestión Ambiental e Hidrolectricidad. Complejo Hidroeléctrico de Salto Grande: un camino hacia la sustentabilidad, 19-22 September 2001, Argentina. Argentina: Complejo Hidroeléctrico de Salto Grande.

CAPRARI, J.J., 2006. Tinturas antiincrustantes. In: G. DARRIGRAN and C. DAMBORENEA, eds. Bio-invasión del mejillón dorado en el continente americano. La Plata: Universidade Nacional de la Plata, pp. 181-205.

COFFMAN, W.P. and FERRIGTON, L.C., 1996. Chironomidae. In: R.W. MERRIT and K.W. CUMMINS, eds. An introduction to the aquatic insect of North America. Dubuque: Kendall Hunt, pp. 635-754.

COURTEMANCH, D. and DAVIES, S.P., 1987. A coefficient of community loss to assess detrimental change in aquatic communities. Water Research, vol. 21, no. 2, pp. 217-222. http:// dx.doi.org/10.1016/0043-1354(87)90052-2.

COUTINHO, R., SOUZA, E.C.F. and HAJE, L., 2012. Tintas anti-inscrustantes no controle do mexilhão-dourado. In: M.C.D. MANSUR, C.P. SANTOS, D. PEREIRA, I.C.P. PAZ, M.L.L. ZURITA, M.T.R. RODRIGUEZ, M.V. NEHRKE and P.E.A. BERGONCI, orgs. Moluscos límnicos invasores no Brasil: biologia, prevenção e controle. Porto Alegre: Redes, pp. 323-327.

DARRIGRAN, G., 2002. Potential impact of filter-feeding invaders on temperate inland freshwater environments. Biological Invasions, vol. 4, no. 1-2, pp. 145-156. http://dx.doi. org/10.1023/A:1020521811416. 
DARRIGRAN, G. and DAMBORENEA, C., 2006. Características de la espécie. In: G. DARRIGRAN and C. DAMBORENEA, eds. Bio-invasión del mejillón dorado en el continente americano. La Plata: Universidade Nacional de la Plata, pp. 53-68.

DARRIGRAN, G. and MANSUR, M.C.D., 2006. Distribución, abundancia y dispersión. In: G. DARRIGRAN and C. DAMBORENEA, eds. Bio-invasión del mejillón dorado en el continente americano. La Plata: Universidade Nacional de la Plata, pp. 93-110.

DARRIGRAN, G. and PASTORINO, G., 1995. The recent introduction of a freshwater Asiatic bivalve, Limnoperna fortunei (Mytilidae) into South America. The Nautilus, vol. 114, no. 2, pp. 69-73.

DARRIGRAN, G., DAMBORENEA, D. and GRECO, N., 2007. Na evaluation pattern for antimacrofouling procedures: Limnoperna fortunei larvae study in a hydroelectric power plant in South America. Ambio, vol. 36, no. 7, pp. 575-579. http:// dx.doi.org/10.1579/0044-7447(2007)36[575:AEPFAP]2.0.CO;2. PMid:18074895.

DARRIGRAN, G., MARTIN, S.M., GULLO, B. and ARMENDARIZ, L., 1998. Macroinvertebrates associated with Limnoperna fortunei (Dunker, 1857) (Bivalvia, Mytilidae) in Río de la Plata, Argentina. Hydrobiol., vol. 367, no. 1-3, pp. 223-230. http:// dx.doi.org/10.1023/A:1003244603854.

EPLER, J.H., 1995. Identification manual for the Larval Chironomidae (Diptera) of Florida. Tallahassee: Florida Department of Environmental Regulation.

FARIA, E.A., BRANCO, J.R.T., CAMPOS, M.C.S., OLIVEIRA, M.D. and ROLLA, M.E., 2006. Estudo das características antiincrustantes de materiais. REM: Revista da Escola de Minas, vol. 59 , no. 2 , pp. 233-238.

FRENCH, M.S. and EVANS, L.V., 1986. Fouling on paints containing copper and zinc. In: L.V. EVANS and K.D. HOAGLAND, eds. Algal Biofouling. The Netherlands: Elsevier Science Publishers, pp. 79-100. Studies in Environmental Science, no. 28.

GARCÍA, M.L. and PROTOGINO, L.C., 2005. Invasive freshwater mollusks are consumed by native fishes in South America. Journal of Applied Ichthyology, vol. 21, no. 1, pp. 34-38. http://dx.doi. org/10.1111/j.1439-0426.2004.00570.x.

HOWELL, D. and BEHRENDS, B., 2006. A review of surface roughness in antifouling coatings illustrating the importance of cutoff length. Biofouling, vol. 22, no. 5-6, pp. 401-410. http:// dx.doi.org/10.1080/08927010601035738. PMid:17178573.

INSTITUTO DE ESTUDOS DO MAR ALMIRANTE PAULO MOREIRA - IEAPM, 2008. Programa de pesquisa para o controle do mexilhão dourado (Limnoperma fortunei) nas águas jurisdicionais brasileira. Arraial do Cabo: IEAPM. 381 p.

KRAFT, K.J. and SYPNIEWSKI, R.H., 1981. Effect of sediment copper on the distribution of benthic macroinvertebrates in the Keweenaw waterway. Journal of Great Lakes Research, vol. 7, no. 3, pp. 258-263. http://dx.doi.org/10.1016/S0380-1330(81)72053-7.

LEARNER, M.A., LOCHHEAD, G. and HUGHES, B.D., 1978. A review of the biology of British Naididae (Oligochaeta) with emphasis on the lotic environment. Freshwater Biology, vol. 8, no. 4, pp. 357-375. http://dx.doi.org/10.1111/j.1365-2427.1978. tb01457.x.

MAASRI, A., FAYOLLE, S., GANDOUIN, E., GARNIER, R. and FRANQUET, E., 2008. Epilithic chironomid larvae and water enrichment: is larval distribution explained by epilithon uantity or quality? Journal of the North American Benthological Society, vol. 27, no. 1, pp. 38-51. http://dx.doi.org/10.1899/07-013R1.1.

MANSUR, M.C.D. and PEREIRA, D., 2006. Bivalves límnicos da bacia do rio dos Sinos, Rio Grande do Sul, Brasil (Bivalvia, Unionoida, Veneroida e Mytiloida). Revista Brasileira de Zoologia, vol. 23, no. 4, pp. 1123-1147. http://dx.doi.org/10.1590/S010181752006000400021 .

MARONAAS, M.E. and DAMBORENEA, C., 2006. Efecto de biocidas y tolerancia a la exposición al aire. In: G. DARRIGRAN and C. DAMBORENEA, eds. Bio-invasión del mejillón dorado en el continente americano. La Plata: Universidade Nacional de la Plata, pp. 167-180.

MARR, J.C.A., LIPTON, J., CACELA, D., HANSEN, J.A., MEYER, J.S. and BERGMAN, H.L., 1999. Bioavailability and acute toxity of copper to rainbow trout (Oncorhyncus mykiss) in the presence of organic acids simulating natural dissolved organic carbon. Canadian Journal of Fisheries and Aquatic Sciences, vol. 56, pp. 1471-1483.

MATSUI, Y., NAGAYA, K., FUNAHASHI, G., GOTO, Y., YUASA, A., YAMAMOTO, H., OHKAWA, K. and MAGARA, Y., 2002. Effectiveness of antifouling coatings and water flow in controlling attachmaent of the nuisance mussel Limnoperna fortunei. Biofouling, vol. 18, no. 2, pp. 137-148. http://dx.doi. org/10.1080/08927010290032395.

OHKAWA, K., NISHIDA, A., HONMA, R., MATSUI, Y., NAGAYA, K., YUASA, A. and YAMAMOTO, H., 1999. Studies on fouling by the freshwater mussel Limnoperna fortunei and the antifouling effects of low energy surfaces. Biofouling, vol. 13, no. 4, pp. 337-350. http://dx.doi.org/10.1080/08927019909378389.

OMAE, I., 2003. General aspects of tin-free antifouling paints. Chemical Reviews, vol. 103, no. 9, pp. 3431-3448. http://dx.doi. org/10.1021/cr030669z. PMid:12964877.

PORTELLA, K.F., JOUKOSKI, A., SILVA, A.S., BRASSAC, N.M. and BELZ, C.E., 2009. Biofouling e biodeterioração química da argamassa de cimento portland em reservatório de usina hidroelétrica. Quimica Nova, vol. 32, no. 4, pp. 1047-1051. http://dx.doi.org/10.1590/S0100-40422009000400037.

RICCIARDI, A., WHORISKEY, F.G. and RASMUSSEN, J.B., 1997. The role of the zebra mussel (Dreissena polymorpha) in structuring macroinvertebrate communities en hard substrata. Canadian Journal of Fisheries and Aquatic Sciences, vol. 54, no. 11, pp. 2596-2608. http://dx.doi.org/10.1139/f97-174.

RIGHI, G., 1984. Oligochaeta. In: R. SCHADEN, org. Manual de Identificação de Invertebrados Límicos do Brasil. Brasília: Conselho Nacional de Desenvolvimento Científico e Tecnológico.

ROBINSON, C.T., MINSHALL, G.W. and RUSHFORTH, S.R., 1990. Seasonal colonization dynamics of macroinvertebrates in an Idaho stream. Journal of the North American Benthological Society, vol. 9, no. 3, pp. 240-248. http://dx.doi.org/10.2307/1467587.

ROSIN, G.C. and TAKEDA, A.M., 2007. Larvas de Chironomidae (Diptera) da planície de inundação do alto rio Paraná: distribuição e composição em diferentes ambientes e períodos hidrológicos. Acta Scientiarum: Biological Sciences, vol. 29, pp. 57-63.

SANSEVERINO, A.M., NESSIMIAN, J.L. and HENRIQUESOLIVEIRA, A.L., 1998. A fauna de Chironomidae (Diptera) em diferentes biótopos aquáticos na serra do Subaio (Teresópolis, RJ). Oecologia Brasiliensis, vol. 5, no. 1, pp. 253-264. http:// dx.doi.org/10.4257/oeco.1998.0501.18. 
SANSEVERINO, A.M. and NESSIMIAN, J.L., 2001. Hábitats de larvas de Chironomidae (Insecta, Diptera) em riachos da Mata Atlântica do estado do Rio de Janeiro. Acta Limnologica Brasiliensia, vol. 13, pp. 29-38.

SANTOS, S.B., THIENGO, S.C., FERNANDEZ, M.A., MIYAHIRA, I.C., GONÇALVES, I.C.B., XIMENES, R.F., MANSUR, M.C.D. and PEREIRA, D., 2012. Espécies de moluscos límnicos invasores no Brasil. In: M.C.D. MANSUR, C.P. SANTOS, D. PEREIRA, I.C.P. PAZ, M.L.L. ZURITA, M.T.R. RODRIGUEZ, M.V. NEHRKE and P.E.A. BERGONCI, orgs. Moluscos límnicos invasores no Brasil: biologia, prevenção e controle. Porto Alegre: Redes, pp. 25-49.

TAKEDA, A.M. and FUJITA, D.S., 2004. Benthic invertebrates. In: S.M. THOMAZ, A.A. AGOSTINO and N.S. HAHN, eds. The Upper Paraná River and its floodplain: physical aspects, ecology and conservation. Leiden: Blackhuys Publishers, pp. 191-208.

TAKEDA, A.M., FUJITA, D.S., FERNANDES, S.E.P., BEHREND, R.D.L. and PINHA, G.D., 2011. Mexilhão-dourado na bacia do Paraná: com ênfase ao estado do Paraná. In: M.A. FERNANDEZ, S.B. SANTOS, A. PIMENTA and S.C. THIENGO, orgs. Tópicos em Malacologia. Rio de Janeiro: Technical Books, pp. 317-323.

TAKEDA, A.M., MANSUR, M.C.D., FUJITA, D.S. and BIBIAN, J.P.R., 2003. Ocorrência da espécie invasora de mexilhão dourado, Limnoperna fortunei (Dunker, 1857), em dois pequenos reservatórios próximos a Curitiba, PR. Acta Biologica Leopoldensia, vol. 25, no. 2, pp. 251-254.

TAKEDA, A.M., SHIMIZU, G.M. and HIGUTI, J., 1997. Variações espaço-temporais da comunidade zoobêntica. In: A.E.A.M. VAZZOLER, A.A. AGOSTINHO and N.S. HAHN, eds. A planície de inundação do Alto Rio Paraná: aspectos fisicos, biológicos e socio-econômicos. Maringá: EDUEM, pp. 157-177.

THOMAZ, S.M., PAGIORO, T.A., BINI, L.M., ROBERTO, M.C. and ROCHA, R.R.A., 2004. Limnological characterization of the aquatic environments and the influence of hydrometric levels. In: S.M. THOMAZ, A.A. AGOSTINO and N.S. HAHN, eds. The Upper Paraná River and its floodplain: physical aspects, ecology and conservation. Leiden: Blackhuys Publishers, pp. 75-102.

TRIVINHO-STRIXINO, S. and STRIXINO, G., 1995. Larvas de Chironomidae (Diptera) do Estado de São Paulo: guia de identificação e diagnose dos gêneros. São Carlos: Programa de Pós-graduação em Ecologia e Recursos Naturais, UFSCar. 229 p.

WOODS HOLE OCEANOGRAPHIC INSTITUTION - WHOI, 1952. Marine fouling and its prevention. Annapolis: United States Naval Institute. $388 \mathrm{p}$.

YEBRA, D.M., KIIL, S. and DAM-JOHANSEN, K., 2004. Antifouling technology: past, present and future steps towards efficient and environmentally friendly antifouling coatings. Progress in Organic Coatings, vol. 50, no. 2, pp. 75-104. http:// dx.doi.org/10.1016/j.porgcoat.2003.06.001. 